\title{
Banking Service in Albania: Satisfied... from what?
}

\author{
Armela Anamali ${ }^{1, *}$, Alma Zisi ${ }^{2}$, Bitila Shosha ${ }^{1}$ \\ ${ }^{1}$ Department of Finance and Accounting, Faculty of Business, University “Aleksander Moisu”, Albania \\ ${ }^{2}$ Department of Economics, Faculty of Business, University “Aleksander Moisu”, Albania
}

Received May 24, 2021; Revised July 22, 2021; Accepted August 22, 2021

\section{Cite This Paper in the following Citation Styles}

(a): [1] Armela Anamali, Alma Zisi, Bitila Shosha , "Banking Service in Albania: Satisfied... from what?," Universal Journal of Accounting and Finance, Vol. 9, No. 4, pp. 735 - 744, 2021. DOI: 10.13189/ujaf.2021.090419.

(b): Armela Anamali, Alma Zisi, Bitila Shosha (2021). Banking Service in Albania: Satisfied... from what?. Universal Journal of Accounting and Finance, 9(4), 735 - 744. DOI: 10.13189/ujaf.2021.090419.

Copyright@2021 by authors, all rights reserved. Authors agree that this article remains permanently open access under the terms of the Creative Commons Attribution License 4.0 International License

\begin{abstract}
relationship between service quality and customer satisfaction from the banking service in Albania. Design/methodology/approach-For the realization of this study, the authors relied on primary data. The population, taken in the study, are the clients of a commercial bank operating in the city of Durrës. The questionnaire is structured with questions on a five-point psychometric scale, grouped for each dimension of quality and the dependent variable of customers' satisfaction. To prove the consistency of the indicators within each factor, the Cronbachs' alpha test was performed, while for the analysis of the functional relationships between the dimensions of service quality and customers' satisfaction, the correlations were tested and the Enter/Stepwise methods were used. The software used for data processing is SPSS V.21. Findings-Customers' satisfaction for the sample taken in the study is dependent on two factors, assurance and responsiveness. Other factors do not directly affect customers' satisfaction with banking services, but are statistically significant related to the independent variables included in the study. Originality/value-This paper tests previously found relationships, but the socio-economic developments, the level of financial culture, and the extent of banking sector in Albania, seem to affect consumers' perceptions of quality and what makes them satisfied. Passing two major financial crises (pyramid schemes in 1997 and the 2008 financial crisis) with a poor financial culture, the Albanian customers expect a quality service in a service that makes them feel safe and is being offered specifically to their expectations.
\end{abstract}

Keywords Service Quality, Customer Satisfaction, Banking Service, Albania
JEL: M, M3, M31

\section{Introduction}

Banking sector is one of Albanian industries where competition is blatantly obvious. The provision of banking services and products has been increasing in number and quality. This sector is consolidated over the years and wide-spread across the country. Considering the latent financial culture, achieving customers' satisfaction and maintaining loyalty is a challenging mission for banks in Albania. Like any service provider, banks must constantly forecast customer's needs and even exceed their expectations. The quality standards implemented by a qualified staff, comfortable premises and explicit practices are not sufficient to satisfy the customer. Surviving in today's competitive market requires a heart to understand customers, a brain to analyze them, and hands to deliver them the best products [1]. Therefore, to achieve this goal, new and different tools and mindsets are required. The peculiar nature of this service industry and the Albanian market where it is developed made us question whether bank service quality remains faithful to all dimensions that literature names as important for customers' satisfaction. The purpose of this study is to measure and demonstrate the effectiveness of each factor in customers' satisfaction and their effects on the banking sector in Albania. So, we will first examine the theoretical background and, then, analyze the collected data. 


\section{Literature Review}

Previous studies reveal that there is no consensus in terms of determinants regulating service quality and customers' satisfaction in banks. They are different for banks in different countries [2]. The consumer needs, wishes and preferences may change at any time making it difficult for the banking industry to get some suggestions [3].

In an aggressive market where businesses compete among themselves for customers, customers' satisfaction is perceived as a key differentiator and an increasing essential element of the business strategy [4]. Customers' satisfaction is considered as the essence of success for the banking industry, which has nowadays become a highly competitive industry [5]. For [6], in a dynamic and competitive environment like the banking environment, it becomes mandatory to find out the customer satisfaction factors. At the same time, customer satisfaction is a dependent and independent variable, often called an intermediary variable. Among factors influencing customers' satisfaction are service quality, environment, participation, accessibility and financial factors of the bank [7]. A satisfied customer can become a loyal customer and a powerful marketing agent for the bank. In his paper, [8] aimed to measure the quality of service in, customer satisfaction and loyalty towards banks. The results of his work showed that providing high-quality service increases customer satisfaction and leads to a greater commitment and loyalty. [9] argue that that compared to dissatisfied customers, the satisfied customers are more likely to recommend their bank to their friends and continue to use the same bank, even resisting the offers of other banks. According to [10], customers' satisfaction strengthens loyalty and return, increases information about the bank, lowers cost of absorbing new customers and prevents competitor firms to influence customers.

\section{Customer satisfaction}

Customers' satisfaction is one of the issues that has earned a lot of attention among academics and business persons, in recent decades. In their study, [11] stress that the competitive power and survival of a bank is based on the degree of customer satisfaction. According to an old definition of [12], customer satisfaction is described as meeting all the expectations the customer has about the product and the feeling or attitude the customer has towards the product/service after using it. In more general terms, customer satisfaction is a psychological state based on the experience of the customer after having consumed (used) the product [13]. A satisfied customer means that he/she experienced a good performance of the service used [14].

The literature on customer satisfaction from services, in general, and banking industry, in particular, is divided in different views interpreting this variable. [15], for example, argue that the level of customer satisfaction can be influenced by various external and internal factors. It is not a static process, but changing over time as the customer is receiving the service [16]. Customer satisfaction is defined as the number of customers whose experiences (ratings) exceed the explicit goals of service satisfaction [4]. If banks want a high customer satisfaction, they need to apply the right approach to customers rather than choosing a strategy that is less costly [17].

\section{Service quality}

When discussing about satisfaction, we are talking about a broad concept with many interpretations. Otherwise, it can be about quality of service. Service quality is linked with customer perceptions of reliability, assurance, responsiveness, empathy and tangible assets that characterize a service [18]. According to [19], the service quality has to do with the extent to which a service can satisfy customer expectations. They argue that the only source to assess service quality are the clients by comparing expectations with the perceptions they had about the service [19].

Some of the main service quality dimensions studied in banking industry are: tangibles, reliability, responsiveness, assurance and empathy [20, 8, 21, 3, 22, 23]. These dimensions were firstly proposed in 1988 by Parasuraman and others with their SERVQUAL model.

According to [20, 8, and 21]:

Tangibles are all things of a service that have physical evidence. These include physical facilities (such as premises, devices and equipment used for service provision) and persons (such as the behavior of the service providing personnel).

Reliability of service has to do with the ability to provide services in a reliable and accurate manner. Service providers make efforts to keep their promises from the very first moment and pay attention to the results achieved.

Responsiveness has to do with employees' willingness to deliver customers proper services, e.g., explaining customers when things will be done and how, paying attention to customers, promoting services and responding to customer's requirements.

Assurance is directly related with knowledge and courtesy of employees; whether they are able to gain the customers' trust and confidence about the services being provided.

Empathy has to do with taking care of customers, conveying the feeling that the customer is unique and special. The customer should perceive and also feel that he/she is treated with utmost care, has all the attention, and is receiving proper service.

\section{Service quality and customer satisfaction}

Service quality is a crucial factor determining customer 
satisfaction in banking industry [24, 3, 8], even for the survival and performance of banks [25, 26]. For the survival and growth of a bank, it is not sufficient the size of funds only, but also the sustainable provision of a quality service [27]. Service quality is considered to be the most powerful competitive weapon of banks [26]. Banks should focus on the degree of customer satisfaction by providing a regular, quality and timely service in order to keep the existing customers and, at the same time, continuously improving quality to attract new [28]. Those banks that provide increasingly quality services have more advantages, as they manage to increase market share, keep clients and increase profits [29]. The literature review on banking services revealed several empirical studies talking about an important correlation between service quality and customer satisfaction and how these two variables are related to other dependent and independent variables [30; 20; 31; 32; 3; 33; 34; 35; 8; 36; 37; 38; etc.)

\section{Study objectives}

In this article, the authors aim to meet the following objectives:

- Literature review referring to the issue taken in the examination.

- Raising the study hypothesis in terms of quality and satisfaction with the banking service in Albania.

- Conducting an empirical research, analysis of correlations between variables and examination of regression model

\section{Study hypothesis}

As mentioned in the literature, service quality and customer satisfaction are two distinct concepts, but closely correlated to one-another [37]. Without measuring customer satisfaction, a bank will not be able to provide better services to its customers. Service quality and customer satisfaction are thus interrelated and play a compelling role in improving the bank's overall performance [26]. In this paper, we will study whether the dimensions of service quality in Albanian banking market equally affect customer satisfaction. Various studies argue that the dimensions have different weight at customer satisfaction than the quality of service [39; 40].

$\mathrm{H}_{1}$ : All dimensions of quality influence the increase of customer satisfaction by banking services in Albania.

\section{Research Methodology}

To carry out this study, we have used a questionnaire referring to similar studies on banking services, quality and customer satisfaction. For the variables included in the study, an average of 3-4 indicators (items) is used for each variable. The questionnaire contains questions measured using Likert scale of 1-5 (very poor to very good), 1-5 (strongly disagree to strongly agree). To test whether these variables are reliable and represent the basic approaches, the Cronbachs Alpha test has been used (table no. 1) to measure the consistence of the structure. For the elements of a bank service quality, our work is based on the study of [41] and for the satisfaction from the banking service the study of [42].

Table 1. Cronbach Alpha for the items used for the variables

\begin{tabular}{|c|c|c|}
\hline Variable & No. of Items & Cronbach Alpha \\
\hline Tangibles & 4 & 0.967 \\
\hline Empathy & 3 & 0,895 \\
\hline Reliability & 3 & 0.755 \\
\hline Assurance & 3 & 0.747 \\
\hline Responsiveness & 3 & 0.730 \\
\hline Costumer Satisfaction & 3 & 0.995 \\
\hline
\end{tabular}

\section{Sampling}

Primary data were collected by using a survey instrument. The questionnaire was distributed in person to respondents and the sample was randomly selected at a private bank in Durrës. The sample size is 100 customers, while the survey was made after they received a bank service. The sample size taken in the study is $100-200$ persons, which according to Anderson and others (1998) (cited by [37]) is considered more suitable for structural equation modeling used during this study.

The sample has an almost equal distribution between the sexes ( $48 \%$ female and the rest male) and distributed by age (24\% in the age range $18-30$ years; $33 \%$ between the ages $31-50$ years and $43 \%$ over 50 years). $63 \%$ of respondents have lower or secondary education, $22 \%$ university education and 15\% postgraduate education.

\section{Data processing and sample description}

The least squares method (LSM) was used to estimate the regression coefficients, while the Pearson coefficient was used to estimate the bivariate correlation relations. The Fisher test was used to estimate the statistical significance of independent variables included in the econometric model. Data processing was made with SPSS V.21 software. To construct the regression equation with the dependent variable "customer satisfaction" and independent variables "service quality dimensions", Enter and Stepwise methods were used.

\section{Outputs and Discussions}

\section{Correlations}

The purpose of studying correlations is to determine 
whether two or more variables are related between them [43]. Table (no.2) below shows that the dependent variable is positively correlated with the independent variables (excluding "tangibles"), but at different levels of statistical significance. Despite tangibles is one of the five dimensions of service quality determining customer satisfaction, the outcomes show that it has no statistically significant correlation with customer satisfaction. However, a statistically significant positive correlation is observed between tangibles and responsiveness and assurance. This shows that this variable combined with other variables can increase customers' perception of a quality service. [44] reached a similar conclusion. He found out that by combining tangible and intangible attributes of quality into products and services provided by banks, they can create a strong and long-term relationship with their customers.

The studies conducted in other countries show that a positive increase in the level of perception for "Reliability", "Responsiveness", and "Assurance and Empathy" variables is highly statistically certain to increase the level of perception of customer satisfaction with the banks. However, "Reliability" and "Empathy" have a moderate impact on the level of "Satisfaction" $(0.3<$ PCC 0.5$)$, while "Responsiveness" and "Assurance" have a statistically significant impact (0.5PCC0.7).

The study of bivariate correlations, for the data presented in this paper, revealed other phenomena, which could be a useful guide for the organizational and operational policies of second-tier banks in Albania. They could be also the object of further studies.

(i) "Responsiveness" is positively correlated with "Reliability" $\left(0.885^{* *}\right)$ and "Assurance" $\left(0.725^{* *}\right)$ within levels classified as very significant, nearly functional statistical correlation $(0.7<\mathrm{PCC}>1.0)$. Otherwise said, such correlative results indicate that an increase in the level of service (staff) responsiveness is highly statistically certain to increase the reliability and assurance that a customer creates with his bank.

(ii) The same could be concluded for "Empathy" with "Reliability" (0.819**) and "Responsiveness" $\left(0.803^{* *}\right)$. So, an increase in the level of "Empathy" is highly statistically certain to increase the level of "Customer Reliability” towards the bank, but also to increase the level of perception that the bank offers a "Responsive" service towards the customer.

Such correlations could be a useful indicator to create new variables, combined between them. Adopting a comparable combination, [21] discovered significant correlations between empathy and responsiveness, defined by them as customer care, and assurance and reliability, defined as professional features.

In the correlation table are observed pairs that are characterized by high correlations (eg between empathy and reliability, PC $=0.819^{* *}$ ), but in the econometric model these pairs do not participate without compromising the quality of the latter.

Table 2. Correlations between variables

\begin{tabular}{|c|c|c|c|c|c|c|c|}
\hline \multicolumn{8}{|c|}{ Correlations } \\
\hline & & Satisfaction & Tangibles & Reliability & Responsiveness & Assurance & Empathy \\
\hline \multirow{2}{*}{ Satisfaction } & PCC & 1 & & & & & \\
\hline & Sig. & & & & & & \\
\hline \multirow{2}{*}{ Tangibles } & PCC & .192 & 1 & & & & \\
\hline & Sig. & .055 & & & & & \\
\hline \multirow{2}{*}{ Reliability } & PCC & $.476^{* *}$ & .166 & 1 & & & \\
\hline & Sig. & .000 & .099 & & & & \\
\hline \multirow{2}{*}{ Responsiveness } & PCC & $.574^{* *}$ & $.448^{* *}$ & $.885^{* *}$ & 1 & & \\
\hline & Sig. & .000 & .000 & .000 & & & \\
\hline \multirow{2}{*}{ Assurance } & PCC & $.585^{* *}$ & $.435^{* *}$ & $.555^{* *}$ & $.725^{* *}$ & 1 & \\
\hline & Sig. & .000 & .000 & .000 & .000 & & \\
\hline \multirow{2}{*}{ Empathy } & PCC & $.376^{* *}$ & .140 & $.819^{* *}$ & $.803^{* *}$ & $.480^{* *}$ & 1 \\
\hline & Sig. & .000 & .163 & .000 & .000 & .000 & \\
\hline
\end{tabular}

Source: Authors' analysis 


\section{Linear regression with ENTER method}

\begin{tabular}{|l|l|l|l|}
\hline Variables Entered/Removed & \\
\hline Model & Variables Entered $^{\text {a }}$ & Variables Removed & Method \\
\hline 1 & $\begin{array}{l}\text { Empathy, Tangibles, Assurance, Reliability, } \\
\text { Responsiveness }\end{array}$
\end{tabular}

\begin{tabular}{|c|c|c|c|c|c|c|c|c|c|}
\hline \multicolumn{10}{|c|}{ Model Summary } \\
\hline \multirow[b]{2}{*}{ Model } & \multirow[b]{2}{*}{$\mathbf{R}$} & \multirow[b]{2}{*}{ R Square } & \multirow{2}{*}{$\begin{array}{l}\text { Adjusted } \\
\text { R Square }\end{array}$} & \multirow{2}{*}{$\begin{array}{l}\text { Std. Error } \\
\text { of the } \\
\text { Estimate }\end{array}$} & \multicolumn{5}{|c|}{ Change Statistics } \\
\hline & & & & & $\begin{array}{c}\text { R Square } \\
\text { Change }\end{array}$ & F Change & df1 & df2 & $\begin{array}{c}\text { Sig. F } \\
\text { Change }\end{array}$ \\
\hline 1 & $.653^{\mathrm{a}}$ & .426 & .395 & .50973 & .426 & 13.948 & 5 & 94 & .000 \\
\hline
\end{tabular}

\begin{tabular}{|c|c|c|c|c|c|c|c|c|}
\hline \multicolumn{9}{|c|}{ Coefficients ${ }^{a}$} \\
\hline & & \multicolumn{2}{|c|}{$\begin{array}{c}\text { Unstandardized } \\
\text { Coefficients }\end{array}$} & \multirow{2}{*}{$\begin{array}{c}\begin{array}{c}\text { Standardized } \\
\text { Coefficients }\end{array} \\
\text { Beta } \\
\end{array}$} & \multirow{2}{*}{ t } & \multirow{2}{*}{ Sig. } & \multicolumn{2}{|c|}{$\begin{array}{c}95.0 \% \text { Confidence } \\
\text { Interval for B }\end{array}$} \\
\hline & & B & Std. Error & & & & $\begin{array}{l}\text { Lower } \\
\text { Bound }\end{array}$ & $\begin{array}{l}\text { Upper } \\
\text { Bound }\end{array}$ \\
\hline \multirow{6}{*}{1} & (Constant) & 1.229 & .529 & & 2.324 & .022 & .179 & 2.280 \\
\hline & Tangibles & -.377 & .174 & -.235 & -2.163 & .033 & -.723 & -.031 \\
\hline & Reliability & -.163 & .241 & -.141 & -.676 & .501 & -.640 & .315 \\
\hline & Responsiveness & .988 & .361 & .759 & 2.735 & .007 & .271 & 1.705 \\
\hline & Assurance & .487 & .175 & .333 & 2.788 & .006 & .140 & .834 \\
\hline & Empathy & -.275 & .168 & -.244 & -1.635 & .105 & -.609 & .059 \\
\hline
\end{tabular}

Source : Authors

Evaluating the multivariate linear regression coefficients with the Enter method, which ensures inclusion of all independent variables in the model with "Satisfaction" as dependent variable, we reach to the conclusion that "Tangibles", "Reliability" and "Empathy" variables do not provide the sufficient level of significance in the linear model (Sig. $=0.501>0.05$ and Sig. $=0.105>0.05$ ). $>$ After excluding non-significant variables and those with functional (multicolineary) correlations with the Stepwise method (as shown in the tables below), we can construct a linear regression model only with "Assurance" and "Responsiveness" as variables. In addition, in terms of appropriateness level, this model is highly appropriate $\left(\mathrm{R}^{2}=0.983\right)$. The constant is excluded from the model because in the Stepwise method, it goes beyond the significance limits.

\section{Linear regression with Stepwise method}

\begin{tabular}{|c|c|l|l|}
\hline \multicolumn{2}{|l|}{ Variables Entered/Removed ${ }^{\text {a,b }}$} \\
\hline Model & Variables Entered & $\begin{array}{l}\text { Variables } \\
\text { Removed }\end{array}$ & Method \\
\hline 1 & Assurance & $\begin{array}{l}\text { Stepwise (Criteria: Probability-of-F-to-enter }<=.050, \\
\text { Probability-of-F-to-remove }>=.100) .\end{array}$ \\
\hline 2 & Responsiveness & $\begin{array}{l}\text { Stepwise (Criteria: Probability-of-F-to-enter }<=.050, \\
\text { Probability-of-F-to-remove }>=.100) .\end{array}$ \\
\hline a. Dependent Variable: Satisfaction & \\
\hline
\end{tabular}




\begin{tabular}{|c|c|c|c|c|}
\hline \multicolumn{5}{|l|}{ Model Summary } \\
\hline Model & $\mathbf{R}$ & R Square $^{\text {b }}$ & Adjusted R Square & Std. Error of the Estimate \\
\hline 1 & $.990^{\mathrm{a}}$ & .981 & .981 & .54519 \\
2 & $.991^{\mathrm{c}}$ & .983 & .983 & .51858 \\
\hline \\
a. Predictors: Assurance \\
b. For regression through the origin (the no-intercept model), R Square measures the proportion of the variability in the dependent variable \\
about the origin explained by regression. This CANNOT be compared to R Square for models which include an intercept. \\
c. Predictors: Assurance, Responsiveness \\
\hline
\end{tabular}

\begin{tabular}{|c|c|c|c|c|c|c|c|c|}
\hline \multicolumn{9}{|c|}{ Coefficients $^{\mathrm{a}, \mathrm{b}}$} \\
\hline \multirow{2}{*}{ Model } & \multicolumn{3}{|c|}{ Unstandardized Coefficients } & \multirow{2}{*}{$\begin{array}{c}\begin{array}{c}\text { Standardized } \\
\text { Coefficients }\end{array} \\
\text { Beta }\end{array}$} & \multirow{2}{*}{$\mathbf{t}$} & \multirow{2}{*}{ Sig. } & \multicolumn{2}{|c|}{$\begin{array}{l}\text { 95.0\% Confidence } \\
\text { Interval for B }\end{array}$} \\
\hline & B & & Std. Error & & & & $\begin{array}{l}\text { Lower } \\
\text { Bound }\end{array}$ & $\begin{array}{l}\text { Upper } \\
\text { Bound }\end{array}$ \\
\hline \multirow{2}{*}{2} & Assurance & .599 & .156 & .527 & 3.828 & .000 & .288 & .909 \\
\hline & Responsiveness & .474 & .140 & .465 & 3.380 & .001 & .196 & .753 \\
\hline \multicolumn{9}{|c|}{ a. Dependent Variable: Satisfaction } \\
\hline \multicolumn{9}{|c|}{ b. Linear Regression through the Origin } \\
\hline
\end{tabular}

\section{Linear regression equation:}

$$
\begin{gathered}
\text { Satisfaction }=0.599 \times \text { (Assurance) }+0.477 \mathrm{x} \\
(\text { Responsiveness })+\varepsilon
\end{gathered}
$$

The statistical processing of linear regression confirms a positive correlation between customer satisfaction and the two dimensions of service quality: Responsiveness and Assurance. [45] mentions Responsiveness as one of the three core dimensions determining service quality. Others define it as the principal factor determining customer satisfaction [46; 47; 48].

The other factor with a significance level (p-value < 0.005 ) in the increase of customer satisfaction is the perceived assurance in receiving banking service. In the study of [22], this variable is the dimension with which customers feel more "comfortable" in terms of banking service. It is believed that if employees of financial institutions have a trustworthy behavior, the level of customer satisfaction may increase significantly [49]. This factor turns out to be the most influential in customer satisfaction in the studies of [50] and [51] and the second after Empathy in [52].

\section{Conclusions}

The purpose and objectives of this paper is to understand whether the literature reviewed and the different studies in marketing of banking services are applicable in the sample taken in our study and can be generalized for the banking system in the country. This study analyzed the correlations between service quality factors and customers' satisfaction in the Albanian banking sector. In addition, we proved the hypothesis rose in our paper.

This article helps banks, monetary organizations, academicians, advisors, and specialists to have a piece of superior information on the driving breaks in retail banking for countries [53], which have a fragile financial system and not lots of information on their clients' perceptions. It is very important that banks set a standard for the variables under review and regularly and systematically monitor their performance both for individual customers and small and medium-companies and joint stock companies. The Albanian customer has a basic financial education and modest financial income, but has priority in the banking service. The analysis made showed that another important factor having a role in the increase of customer satisfaction by banking services, is also the perceived assurance in obtaining banking service.

Strictly speaking, the results concern only the respondents and the population in general. As in the study of [54], where the selection of regions and cities is made based on the influence they have, this study is focused on the city of Durres as a location which is closest to the capital, the only active airport in Albania, and has the main seaport in the country. The sample size is not big but appropriate for the type of analysis, sampling and outputs achieved in this paper. However, the results indicate a statistically significant positive correlation between Tangibles and Responsiveness and Assurance. This shows that although Tangibles do not influence directly customers' perception of satisfaction with the banking service, when combined with other factors it has an impact on increasing customers' perception of a quality service.

This study could be the baseline for future research. The role and value of correlation between customer satisfaction and loyalty can be a wide and interesting field of study. Studying the correlations between the data presented in this paper revealed also other phenomena, which could be a useful guide for the organizational and operational policies of second-tier banks in our country. The role of bank's 
reputation or image is important for further studies.

As shown by studies conducted in other countries, a positive increase in the level of perception for "Reliability", "Responsiveness", "Assurance” and "Empathy” variables is highly statistically certain to increase the level of perception of bank's customer satisfaction.

Referring to other studies in other countries, but also based on our statistical analysis, we observed that a positive increase in the level of perception for "Reliability", "Responsiveness", “Assurance” and "Empathy” variables is highly statistically certain to increase the level of perception of bank's customer satisfaction .

These two variables are considered crucial as they are an integral part of the nature of the transactions. The Albanian customer has a basic financial education and modest financial income, but has priority in the banking service.

\section{Limitations of the Study}

- Customers were selected only at a private bank in Durrës, so the results of the study cannot be generalized for all banks.

The method used for data collection cannot exclude sampling errors.

Each study has its own demographic, geographical, cultural and time specifics. This sample contains individual clients, so it excludes businesses.

- Therefore, the results of this study should be used carefully in making generalizations.

\section{Appendix}

\begin{tabular}{|l|l|}
\hline \multicolumn{1}{|c|}{ Variable } & \multicolumn{1}{c|}{ Items used for the variable } \\
\hline $\begin{array}{l}\text { Costumer Satisfaction } \\
\text { (1- Strongly disagree to 5- Strongly } \\
\text { agree) }\end{array}$ & $\begin{array}{l}\text { I am happy with the decision to use this bank. } \\
\text { Choosing this bank has been a smart choice. } \\
\text { Taking everything into consideration, I am satisfied with the services and products of this bank. }\end{array}$ \\
\hline $\begin{array}{l}\text { Tangibles } \\
\text { (1- Strongly disagree to 5-Strongly } \\
\text { agree) }\end{array}$ & $\begin{array}{l}\text { The equipment used in this bank looks very modern. } \\
\text { The reception system of this bank is very good. } \\
\text { The physical structures of this bank are visually very attractive. } \\
\text { The presentation of the bank statements is very clear. }\end{array}$ \\
\hline $\begin{array}{l}\text { Empathy } \\
\text { (1-Very poor to 5- Very good) }\end{array}$ & $\begin{array}{l}\text { The courtesy and education of the employees in this bank is: } \\
\text { The friendly and pleasant behavior of the employees in this bank is: } \\
\text { The help of the staff in this bank is: }\end{array}$ \\
\hline $\begin{array}{l}\text { Reliability } \\
\text { (1-Very poor to 5-Very good) }\end{array}$ & $\begin{array}{l}\text { The service provided by the staff for the first time was: } \\
\text { Clarity and readability of information on billing (costs) of transactions is: } \\
\text { Internet /telephone services offered are: }\end{array}$ \\
\hline $\begin{array}{l}\text { Assurance } \\
\text { (1-Very poor to 5-Very good) }\end{array}$ & $\begin{array}{l}\text { Employee knowledge for service I had were: } \\
\text { The feeling of trust that the bank employees created in me was: } \\
\text { The comunication and the approach used tward me was: }\end{array}$ \\
\hline $\begin{array}{l}\text { Responsiveness } \\
\text { (1-Very poor to 5-Very good) }\end{array}$ & $\begin{array}{l}\text { The readiness of the staff to respond to your request at this bank is: } \\
\text { The speed in performing the service in this bank is: } \\
\text { Service personnel are }\end{array}$ \\
\hline
\end{tabular}




\section{REFERENCES}

[1] Jonathan M., Richard W. P., "Are Home Prices the Next "Bubble”?", Economic Policy Review, vol.10, no. 3, pp. 1-17, 2004

[2] Win Lin Ch., Shih Y.C., " Hong Kong Housing Markets: Overview, Tenure Choice, and Housing Demand ", Journal of Real Estate Finance and Economics, vol. 10, pp. 7-21, 1995. https://doi.org/10.1007/BF01099608

[3] Akbar D. G., Mohamad S. Z., "The impact of CRM on customer loyalty in Malaysia”, International Conference on Electrical Engineering and Informatics, Selangor, pp. 309-313, 2009. DOI: 10.1109/ICEEI.2009.5254722

[4] Rajagopal S., Velmurugan G., “A review of service quality and customer satisfaction in banking services: global scenario", The Journal of Internet Banking and Commerce, 21(5), pp. 1-9, 2016. https://www.icommercecentral.com/o pen-access/a-review-of-service-quality-and-customer-satisf action-in-banking-services-global-scenario.php?aid=79699.

[5] Jayaraman M., J., Shankar C.., \& Hor, W. M., "Service Quality Delivery and Its Impact on Customer Satisfaction in the Banking Sector in Malaysia”,International Journal of Innovation, Management and Technology, 1(4), pp. 398-404, 2010. http://ijimt.org/papers/71-M461.pdf

[6] D. Sivakami, K. Vishvanathan, "Costumer Satisfaction towards Banking Services - A study with special reference to private sector banks in Erode District”, International Journal of Trend in Scientific Research (IJTSRD), ISSN No 2456-6470, Vol. 2 (1), pp. 1366-1372, 2017. https://doi.org/10.31142/ijtsrd8230

[7] Sefer G., Sudi A., Tuğbay B G., Hande G. G., Serpil G., "Ultimate Point in the Service Provided by the Banks to Their Customers: Customer Satisfaction in the Common Use of ATMs”, Procedia - Social and Behavioral Sciences (207), pp. 98-110, 2015. DOI: 10.1016 / j.sbspro.2015.10.155

[8] Munish K., Sandhir S., "Customer Satisfaction trends in Banking Industry A Literature Review, International”, Journal of applied Business and Economic Research, ISSN: 0972-7302, Vol. 15, (9), pp. 375-381, 2017. http://www.academia.edu/33170635/Customer_Satisfaction _trends_in_Banking_Industry-_A_Literature_Review

[9] Aayushi G., Santosh D., "Client satisfaction in Indian banks: an empirical study”, Management Research Review, Emerald Group Publishing, Vol. 35(7), pp 617-636, 2012. DOI: $10.1108 / 01409171211238839$

[10] Mesay S. S., "Bank Service Quality, Customer Satisfaction and Loyalty in Ethiopian Banking Sector" Journal of Business Administration and Management Sciences Research Vol. 1(1), pp. 1-9, 2012. https://www.researchgate.net/publication/256196617_Bank _Service_Quality_Customer_Satisfaction_and_Loyalty_in_ Ethiopian_Banking_Sector

[11] Anna C., Lenka G., Jaroslav B., Juraj S., “Bank Customers' Satisfaction, Customers’ Loyalty and Additional Purchases of Banking Products and Services. A Case Study from the Czech Republic”, Economics and Sociology, Vol. 8(3), pp.
82-94, 2015. DOI: 10.14254/2071-789X.2015/8-3/6

[12] Paul J P., Jerry C. O. "Consumer behaviour and marketing strategy” New York: The McGraw-Hill Companies, Inc, 2015.

[13] Jelena T., Natalja L., “Customer Satisfaction and Loyalty in Latvian Retail Banking”, Economics and Management, Vol 15, pp.1031-1038, 2010.https://www.researchgate.net/profi le/Jelena_Titko/publication/266233726_CUSTOMER_SAT ISFACTION_AND_LOYALTY_IN_LATVIAN_RETAIL BANKING/links/545dc32e0cf2c1a63bfa69cf/CUSTOME R-SATISFACTION-AND-LOYALTY-IN-LATVIAN-RET AIL-BANKING.pdf

[14] Richard L. O., "A cognitive model of the antecedents and consequences of satisfaction decisions", Journal of Marketing Research, Vol.19(4), pp. 460, 1980. https://doi.org/10.2307/3150499

[15] Richard A.H., Llary P.P, “Categories of customer loyalty: An application of the customer loyalty classification framework in the fast-food hamburger Market.” Journal of Food Products Marketing , Vol. 3(1), pp. 1 - 12, 1996. https://doi.org/10.1300/J038v03n01_01

[16] Michael D. J. ,Claes F, “A Framework for comparing customer satisfaction across individuals and product categories”, Journal of Economic Psychology, Vol.12 (2), pp. 267-286, 1991. https://doi.org/10.1016/0167-4870(91)9001 $6-\mathrm{M}$

[17] Dayang N M A A., Francine R., "Influence of Service and Product Quality towards Customer Satisfaction: A Case Study at the Staff Cafeteria in the Hotel Industry" International Journal of Economics and Management Engineering, Vol.3 (5), pp 346-351, 2009. https://doi.org/10.5281/zenodo.1085115

[18] Cleopatra V., G. Ronald G., Luiz A. M, Mark M.H. G, "Measuring transaction - specific satisfaction in services: Are the measures transferable across cultures?", European Journal of Marketing, Vol. 39 (5/6), pp. 606-628, 2005. https://doi.org/10.1108/03090560510590737

[19] Marcin P., Lisa McQ., “An empirical investigation of customer satisfaction and loyalty across two divergent bank segments”. J Financ Serv Mark Vol. 9, pp.344-359, 2005. https://doi.org/10.1057/palgrave.fsm.4770165

[20] K. M. Salah U., Nymatul J N., Mamunur R., Identification the Factors Influencing Customer Satisfaction on Service Quality in Jamuna Bank, International Journal of Business and Economics Research. Vol. 4, (2), 2015, pp. 30-35. doi: 10.11648/j.ijber.20150402.12

[21] Kasper, H., Helsdingen, P. v., and Vries, W. d., Services Marketing Management: an International Perspective. Wiley; 1st edition ISBN-10 : 0471984906, 1999.

[22] Walfried M. L., Chris M., Robert D. W., "Service quality perspectives and satisfaction in private banking", The Journal of Services Marketing, Vol. 14 (3), pp.244-71, 2000. DOI: $10.1108 / 08876040010327248$

[23] Miklós P., Hossam H., János N., József P., Judit O., "The Service Quality Dimensions that Affect Customer Satisfaction in the Jordanian Banking Sector" Sustainability Vol. 11, (4), pp. 2019. https://doi.org/10.3390/su11041113 
[24] Kingshuk A., Mounita N., "Service Quality and Customer Satisfaction in Commercial Banks: An Empirical Study", A Journal of Humanities \& Social Science, Vol.2, (3), pp. 115-124., 2014. https://www.researchgate.net/publication/2 82862870_Service_Quality_and_Customer_Satisfaction_in _Commercial_Banks_An_Empirical_Study

[25] Srinivas D., N. Hanumantha R., "Service Quality in Commercial Banks: A Study of Public Sector Banks in Warangal District”, Journal of Management, Vol.5, (4), , pp. 9-17. 2018. https://www.researchgate.net/publication/3262 92909_SERVICE_QUALITY_IN_COMMERCIAL_BAN KS_A_STUDY_OF_PUBLIC_SECTOR_BANKS_IN_W ARANGAL_DISTRICT

[26] Yonggui W., Hing - P. L., Yer V. H., “The antecedents of service quality and product quality and their influences on bank reputation: evidence from banking industry in China”, Managing Service Quality, Vol.13, (1), pp.72-83, 2003. https://doi.org/10.1108/09604520310456726

[27] Benjamin O E., (2006), "Correlates of customer loyalty to their bank: a case study in Nigeria", International Journal of Bank Marketing, Vol. 24 (7), pp. 494-508, 2006. https://doi.org/10.1108/02652320610712102

[28] Kingshuk A., Biswajit P., "Perceived Service Quality and Customer Satisfaction in Public Sector Banks: An Empirical Study”. Vidyasagar University Journal of Commerce, Vol. 20, pp.151-159, 2015. http://inet.vidyasagar.ac.in:8080/jspu i/handle/123456789/1026

[29] R.D. Sharma \& Jyoti S ,"Measurement of Customer Delight in Indian Urban consumer Banking, The Indian Journal of Commerce”, 59 (3), pp.61-75, 2006.

[30] Manoj Kr. P., Arup B.,“Customers’ Satisfaction - the Ignored Phenomenon: A Case Study in Rural Banking”, Indian Journal of Commerce, Vol.63 (1), pp.21-35, 2010. https://ssrn.com/abstract=1686503

[31] William J.B., Robert B. H.,"Increasing Service Quality in Retail Banking”, Journal of Retail Banking” Vol. 15(3 ), pp.21-28, 1993.

[32] Richard A.S., Robert D.M., “An empirical examination of a model of perceived service quality and satisfaction”, Journal of Retailing, Vol.72 (2), pp.201-14, 1996. https://doi.org/10.1016/S0022-4359(96)90014-7

[33] Ruth N. B., James H. D., “A Multistage Model of Customers’ Assessments of Service Quality and Value," Journal of Consumer Research, Vol. 17, pp.375-384, 1991. https://www.jstor.org/stable/2626833

[34] Rahim M., Osman M., T. R., "Service quality, customer satisfaction and loyalty: A test of mediation", International Business Research, Vol. 3 (4), pp.72-80, 2010. https://doi.org/10.5539/ibr.v3n4p72

[35] Ahmad J., Kamal N., "Customer satisfaction and retail banking: an assessment of some of the key antecedents of customer satisfaction in retail banking”, International Journal of Bank Marketing, Vol. 20 (4), pp. 146-60, 2002. https://doi.org/10.1108/02652320210432936

[36] Terrence L., T. Gordon H.G. M., "Determinants of Customer Satisfaction in Retail Banking”, International Journal of Bank Marketing, Vol.14(7), pp.12-20, 1996 https://doi.org/10.1108/02652329610151340
[37] Albert C.. , "Service Loyalty. The Effects of Service Quality and The Mediating Role of Customer Satisfaction", European Journal of Marketing, Vol.36(7/8), pp.811-828, 2002. DOI:10.1108/03090560210430818

[38] Mustafa R. R. , Faran A. Q. Mohammad I., “Service Quality, Customer Satisfaction and Customer Loyalty: An Empirical Study On Banks In India,VFAST", Transactions on Education and Social Sciences, Vol.5 (1), pp.39-47, 2017. DOI: http://dx.doi.org/10.21015/vtess.v11i2.427

[39] Kazi O. S., “Interrelations between Service Quality Attributes, Customer Satisfaction and Customer Loyalty in the Retail Banking Sector in Bangladesh”, International Journal of Business and Management, Vol. 6 (3), pp. 12-36, 2011. DOI:10.5539/ijbm.v6n3p12

[40] Maka S. B., "Customer Satisfaction with Indian Mobile Services", The IUP Journal of Management Research, Vol. 8 (10), pp. 52-62, 2009. SSRN: https://ssrn.com/abstract=148 3604

[41] Jayalakshmi G., Bibhu B. M., Vijay K. G., Adimoolam V., "The Impact of Service Quality and Customer Satisfaction on Customer Retention in the Indian Banking Industry: An Empirical Analysis”, Research Journal of Social Science and Management, Vol. 1 (3), pp. 52-68, 2011. http://www.theinternationaljournal.org/ojs/index.php?journ al=tij\&page $=$ article\&op=download\&path\%5B $\% 5 \mathrm{D}=82 \& p a$ th\%5B\%5D=pdf

[42] Maya B. L., Pooja B., “Assessment of Service Quality in Public and Private Sector Banks of India with Special Reference to Lucknow City”, International Journal of Scientific and Research Publications, Vol. 2 (10), pp. 1-7, 2012. http://citeseerx.ist.psu.edu/viewdoc/download?doi=1 0.1.1.375.6016\&rep=rep1\&type=pdf

[43] Norizan, M. K. \& Nizar, S., “Customer Retention Measurement in the UAE Banking Sector", Journal of Financial Services Marketing, Vol. 11(3), pp. 217-228, 2007. https://doi.org/10.1057/palgrave.fsm.4760040

[44] Paul G.P., Tasman S., "A cross-cultural study of switching barriers and propensity to stay with service provider", Journal of Retailing, Vol. 79 , pp. 107 - 120, 2003. https://doi.org/10.1016/S0022-4359(03)00009-5

[45] Mary B., (2001). University of North Texas Center for Parent Education Website: http://www.unt.edu/cpe/module 3blk2survey2.html

[46] Mosad Z., "Quality and customer relationship management (CRM) as competitive strategy in the Swedish banking industry”, The TQM Magazine, Vol. 17(4), pp. 329- 344, 2005. DOI:10.1108/09544780310487749

[47] Firdaus A.,Rosita S., Gluma S., Jamil H., "Bank service quality (BSQ) index: an indicator of service performance”, International Journal of Quality \& Reliability Management, Vol. 28 (5), pp. 542-555, 2011. DOI: $10.1108 / 02656711111132571$

[48] Abbas N. A., “Applying a SERVQUAL Model to Measure the Impact of Service Quality on Customer Loyalty among Local Saudi Banks in Riyadh”, American Journal of Industrial and Business Management, Vol. 3, pp. 700-707, 2013. http://dx.doi.org/10.4236/ajibm.2013.38079

[49] Salman K., Babak M., Muzaffar A., Shabbir H., “Customer 
Satisfaction with Service Quality in Conventional Banking in Pakistan: The Case of Faisalabad”, International Journal of Marketing Studies, Vol. 3(4), 2011. https://doi.org/10.5539/ijms.v3n4p165

[50] Rishi K., Deepak J., “The impact of perceived service quality dimensions on customer satisfaction: An empirical study on public sector banks in India”, Int. J. Bank Mark. Vol. 35, pp. 411-430, 2017. DOI:10.1108/IJBM-04-2016-0051

[51] Mubbsher M. K., Mariam F., "Impact of Service Quality on Customer Satisfaction and Customer Loyalty: Evidence from Banking Sector”, Pakistan Journal of Commerce and Social Sciences, Vol. 8 (2), pp. 331- 354, 2014. http://hdl.handle.net/10419/188141
[52] Anber A. S. M., Shireen Y. M . A., "Service Quality Perspectives and Customer Satisfaction in Commercial Banks Working in Jordan”, Middle Eastern Finance and Economics, Vol. 14, pp. 60-72, 2011. http://www.eurojournals.com/MEFE.htm

[53] Gangu N. M., Meenakshi V., Anuj V., Pushpanatham A., "Service Quality of CRM: With Reference to Public and Private Banks in Nagpur City," Universal Journal of Accounting and Finance, Vol. 9, No. 2, pp. 191 - 196, 2021. DOI: 10.13189/ujaf.2021.090207.

[54] Vitalii R., Oksana G, Nina D, Nataliia K., Oleksii V., Alla S., "Financial Convergence as a Mechanism for Modifying Sectors of the Global Financial Services Market," Universal Journal of Accounting and Finance, Vol. 9, No. 1, pp. 65 - 73, 2021. DOI: 10.13189/ujaf.2021.090107. 